\title{
Implementasi Model Pembelajaran Think Aloud Pair Problem Solving (TAPPS) Untuk Meningkatkan Kemampuan Pemecahan Masalah di Program Studi Akuntansi
}

\author{
Khairaningrum Mulyanti ${ }^{1}$ \\ Prodi D4 Akuntansi Politeknik Pos Indonesia \\ Email: khairaningrum@poltekpos.ac.id
}

\begin{abstract}
ABSTRAK
Dalam Bidang Akuntansi, kemampuan pemecahan masalah diimplementasikan dalam kemampuan untuk memilih dan mengembangkan solusi yang tepat menurut kaidah akuntansi untuk menyelesaikan masalah dan mampu melakukan riset dalam memberikan berbagai alternatif penyelesaian. Salah satu faktor yang mempengaruhi kemampuan pemecahan masalah mahasiswa adalah model pembelajaran yang diterapkan oleh pengajar. Salah satu teknik pembelajaran kolaboratif yang termasuk dalam kategori menyelesaikan masalah adalah Think-Aloud Pair Problem Solving (TAPPS) yang dapat diartikan sebagai menyelesaikan masalah berpasangan secara lisan. Penelitian ini bertujuan untuk melihat sejauh mana keberhasilan model pembelajaran TAPPS ini dalam meningkatkan kemampuan pemecahan masalah mahasiswa jika dibandingkan dengan pelaksanaan pembelajaran menggunakan model ekspositori. Penelitian ini dilakukan dengan metode kuasi eksperimen, dengan subjek penelitian mahasiswa dalam perkuliahan Praktikum Akuntansi Dasar di Politeknik Pos Indonesia dengan metode analisis menggunakan uji independent sample t-test $N$-Gain. Dengan menggunakan bantuan SPSS V.23 didapatkan hasil bahwa terdapat perbedaan peningkatkan kemampuan pemecahan masalah mahasiswa antara kelas eksperimen dengan kelas kontrol. Dari pengujian tersebut juga didapatkan hasil bahwa model pembelajaran TAPPS lebih baik dalam meningkatkan kemampuan pemecahan masalah mahasiswa dalam perkuliahan Praktikum Akuntansi Dasar dibandingkan dengan model pembelajaran ekspositori.
\end{abstract}

Kata Kunci: Kemampuan Pemecahan Masalah, Pembelajaran kolaboratif, Think-Aloud Pair Problem Solving (TAPPS)

\section{ABSTRACT}

In the field of accounting, the ability to solve problems is implemented in the ability to choose and develop appropriate solutions according to accounting principles to solve problems and be able to conduct research in providing various alternative solutions. One of the factors influencing students' problem solving abilities is the learning model applied by the lecturer One of the collaborative learning techniques included in the problem solving category is Think-Aloud Pair Problem Solving (TAPPS) which can be interpreted as solving paired problems verbally. This research aims to see the extent of the success of this TAPPS learning model in improving students' problem solving skills when compared with the implementation of learning using expository models. This research was conducted with a quasi-experimental method, with the subject of student research in the lecture of Basic Accounting Practicum in Polytechnic Pos Indonesia with the analysis method using the N-Gain independent sample t-test. By using SPSS V.23, the results show that there are differences in improving students' problem solving abilities between the experimental class and the control class. The test also shows that the TAPPS learning model is better in improving students' problem solving skills in Basic Accounting Practicum lectures compared to expository learning models.

Keywords: Problem Solving Capabilities, Collaborative Learning,Think-Aloud Pair Problem Solving (TAPPS) 


\section{PENDAHULUAN}

\section{Latar Belakang}

Peningkatan mutu pendidikan sangat berpengaruh kepada para lulusan yang siap menghadapi tuntutan industri. Salah satu cara yang dilakukan oleh Pemerintah adalah menyusun Kerangka Kualifikasi Nasional Indonesia (KKNI). Dalam KKNI jenjang pendidikan S1/D4 di level kualifikasi 6 (enam), terdapat dua paragraf yang menitikberatkan pada kemampuan penyelesaian masalah. Pentingnya kemampuan pemecahan masalah ini menjadikan kemampuan tersebut sebagai salah satu kompetensi yang harus dimiliki oleh Sumber Daya Manusia abas XXI menurut $21^{\text {st }}$ Century Partnership Learning Framework. Seluruh Program Studi menjadikan KKNI sebagai tolok ukur keberhasilan proses pendidikan, begitu juga dalam Program Studi Akuntansi. Lulusan dari program akuntansi harus memiliki beberapa kualifikasi yang terkait dengan kemampuan pemecahan. Diantaranya adalah mampu memilih dan mengembangkan solusi yang tepat dan benar menurut kaidah akuntansi untuk menyelesaikan masalah dibidang akuntansi dan mampu melakukan riset yang dapat digunakan dalam memberikan berbagai alternatif penyelesaian masalah di bidang akuntansi. Salah satu pemasalahan yang sering muncul dalam pembelajaran akuntansi adalah seringnya mahasiswa tidak dapat menyelesaikan permasalahan yang diberikan berupa soal-soal yang bervariatif. Artinya, mahasiswa hanya dapat menyelesaikan soal yang diberikan sesuai dengan contoh yang diberikan pada saat dosen menyampaikan materi perkuliahan. Hal tersebut mengindikasikan bahwa kemampuan pemecahan masalah mahasiswa dalam pembelajaran akuntansi masih rendah.

[1] mengungkapkan ada 4 (empat) tahapan pemecahan masalah yang dapat digambarkan sebagai berikut: 1.Tahap Memahami Masalah (Understanding); 2. Tahap Pemikiran Suatu Rencana (Planning); 3. Tahap Pelaksanaan Rencana (Solving); 4. Tahap Peninjauan Kembali (Checking). Kemampuan pemecahan masalah ini merupakan keterampilan yang dapat dibentuk dan dilatih. Salah satunya melalui model pembalajaran yang diterapkan dalam proses pembelajaran. Metode pembelajaran yang banyak digunakan saat ini belum dapat mengasah kemampuan analisis, melatih pemecahan masalah serta kemampuan mengevaluasi permasalahan secara holistik. Pembelajaran yang baik adalah pembelajaran yang memberikan kesempatan kepada mahasiswa untuk membangun pengalaman melalui berbagai cara untuk selanjutnya dapat memecahkan permasalahan yang berkaitan dengan materi yang disampaikan. Pembelajaran sejenis itu sering disebut sebagai pembelajaran kolaboratif. Ada tiga fitur penting yang diungkapkan oleh [2] mengenai pembelajaran kolaboratif. Fitur yang pertama dari pembelajaran kolaboratif adalah desain yang disengaja. Fitur yang kedua adalah kerja sama, istilah kolaboratif berasal dari bahasa Latin yaitu collaborate yang berarti bekerjasama. Setiap anggota kelompok harus harus bekerja sama secara aktif untuk meraih tujuan yang telah ditentukan. Fitur yang terakhir adalah terjadinya proses pembelajaran yang penuh makna.

Kerjasama yang dilakukan oleh peserta didik dalam proses pembelajaran kolaboratif didasari oleh teori yang diungkapkan oleh Vygotsky yangdinamakan pemagangan kognitif (cognitive apprenticeship) [3]. Dalam mengontruksi pengetahuannya, seringkali mahasiswa memerlukan scaffolding. Scaffolding merupakan pengaturan dan panduan yang diberikan oleh orang dewasa atau teman sebaya yang lebih mampu. Salah satu model pembelajaran yang menggunakan scaffolding sebagai arah pelaksanaannya adalah pembelajaran kolaboratif teknik Think-Aloud Pair Problem Solving (TAPPS), yang dapat diartikan sebagai menyelesaikan masalah berpasangan secara lisan. TAPPS merupakan kombinasi dari thinking-aloud dan teachback techniques. [2] menyebutkan dalam TAPPS, pasangan mahasiswa menerima sejumlah masalah dan juga berperan sebagai problem solver-penyelesai masalah, dan listener-pendengar

Beberapa implementasi penggunaan model pembelajaran TAPPS menunjukan hasil yang positif dalam pembelajaran di bidang teknik dan matematika, dengan jenjang Pendidikan yang berbeda. Dengan keberhasilan penerapan model pembelajaran TAPPS di bidang dan jenjang yang berbeda, 
penelitian ini memiliki tujuan khusus yaitu mengimplementasikan model pembelajaran tersebut dalam perkuliahan Praktikum Akuntansi Dasar serta mengukur sejauh mana keberhasilan model pembelajaran TAPPS ini dalam meningkatkan kemampuan pemecahan masalah mahasiswa jika dibandingkan dengan pelaksanaan pembelajaran menggunakan model ekspositori.

\section{METODE PENELITIAN}

\subsection{Metode Penelitian}

Metode penelitian yang digunakan dalam penelitian ini adalah metode eksperimen semu (quasi experiment) dengan menggunakan perumusan masalah komparatif.

\subsection{Alur Penelitian}

Secara garis besar penelitian ini dilakukan dalam tiga tahap, yaitu tahap persiapan penelitian, tahap pelaksanaan penelitian, tahap akhir penelitian.

\subsubsection{Tahap Persiapan}

Pada tahap ini, peneliti melakukan identifikasi terhadap permasalahan yang terjadi di lapangan, melihat berbagai penyebab dari permasalah yang muncul serta mencari hal-hal yang dapat mempengaruhi perbaikan dalam permasalahan tersebut.

\subsubsection{Teknik Pengumpulan Data}

Teknik pengumpulan data merupakan cara atau metode yang digunakan peneliti untuk mengumpulkan data. Dalam penelitian ini digunakan beberapa teknik pengumpulan data, yaitu melalui tes, studi dokumentasi, dan studi literatur. Instrument yang digunakan juga mengacu pada hal tersebut. Yaitu tes kemampuan pemecahan masalah. Tes kemampuan pemecahan masalah Akuntansi dalam penelitian ini adalah menggunakan tes uraian. Peneliti memilih tes uraian dalam penelitian ini karena dengan dalam penyelesaian soal urain, proses berpikir mahasiswa, pemahaman terhadap masalah, langkah-langkah pengerjaan, langkah-langkah pemecahan masalah, serta ketelitian mahasiswa dalam menyelesaikan soal akan terlihat. Pemberian tes dilakukan melalui pretest dan posttest dengan pedoman penilaian mencakup indikator pemecahan masalah yang dikemukakan oleh [1] yang diadaptasi dari problem Solving Rubric National Central for Research on Evaluation, Standards, and Student Testing (CRESST)

\subsubsection{Populasi dan Sampel}

Populasi dalam penelitian ini adalah seluruh mahasiswa Program Studi D4 Akuntansi Keuangan Politeknik Pos Indonesia yang berjumlah 300 orang. Teknik Sampling nonprobability sampling purposive sampling. Menurut [4]"purposive sampling adalah teknik penentuan sampel dengan pertimbangan atau tujuan tertentu". Alasan peneliti memilih sampel ini karena peneliti ingin mengetahui kemampuan pemecahan masalah dalam mata kuliah Praktikum Akuntansi Dasar. Materi tersebut ada di dalam kurikulum pembelajaran di tingkat pertama. Oleh sebab itu dalam penelitian ini yang dijadikan sampel adalah mahasiswa tingkat pertama Program Studi D4 Akuntansi. Mahasiswa tingkat pertama di program studi ini dibagi menjadi dua kelas, yaitu kelas A dan Kelas B. Jumlah sampel dari kedua kelas tersebut adalah 66 orang Kedua kelas ini digunakan dalam penelitian quasi eksperimen sehingga kedua kelas ini akan dijadikan kelas kontrol dengan menggunakan pembelajaran ekspositori dan kelas treatment (eksperimen) dengan menggunakan pembelajaran kolaboratif teknikThink Aloud Pair Problem Solving (TAPPS). 


\subsubsection{Tahap Pelaksanaan}

Ada beberapa kegiatan yang dilakukan peneliti pada tahap pelaksanaan ini. Kegiatan awal dalam tahap ini adalah pretest atau tes awal. Pretest dilakukan pada masing-masing kelas, kelas kontrol diberikan pretest berupa tes pemecahan masalah begitu juga pada kelas eksperimen. Tahapan berikutnya adalah melakukan implementasi pembelajaran TAPPS kepada mahasiswa di kelas eksperimen dan pembelajaran ekspositori pada kelas kontrol. Kegiatan akhir dalam tahap pelaksanaan adalah pemberian posttest.

\subsubsection{Tahap Penyusunan Laporan}

Kegiatan pertama dalam tahap ini adalah pengolahan data kuantitatif sesuai dengan pertanyaan penelitian yang tercantum dalam rumusan masalah. Data kuantitatif tersebut berupa skor pretest dan posttest, dan N- gain untuk kemampuan pemecahan masalah. Setelah menganalisis gain score dari masingmasing kelas, peneliti melakukan analisis data kuantitatif dari kelas kontrol dan kelas eksperimen menggunakan uji statistik. Teknik analisis kuantitatif tersebut menggunakan alat bantu statistik yaitu SPSS for windows version 23.00. Tahapan awal yang dilakukan oleh peneliti adalah uji normalitas, uji homogenitas, sehingga dari hasil pengujian tersebut peneliti akan menentukan alat uji beda yang akan digunakan. Jika hasil pengujian n-gain menunjukkan hasil normal dan homogen, maka selanjutnya pengujian yang dilakukan menggunakan statistik parametik uji independent sample t-test. Sedangkan apabila hasil pengujian normalitas dan homogenitas memperlihatkan hasil yang negatif, maka pengujian akan menggunakan statistik non parametrik uji Wilcoxon.

\section{HASIL DAN PEMBAHASAN}

\subsection{Hasil Penelitian}

\subsubsection{Implementasi Pembelajaran Kolaboratif Teknik Think Aloud Pair Problem Solving (TAPPS)}

Penelitian yang dimulai pada tanggal 5 Juli 2019. Total pelaksanaan implementasi pembelajaran TAPPS ini dilakukan sebanyak 4 kali termasuk pretest dan post test serta pelaksanaan pembelajaran TAPPS secara menyeluruh sebanyak 2 kali pertemuan. Pertemuan pertama digunakan peneliti untuk melaksanakan pretest yang diperlukan untuk mengetahui bagaimana kemampuan awal dari mahasiswa yang ada di kelas eksperimen. Proses pembelajaran kolaboratif teknik TAPPS yang dilakukan selama proses penelitian dilaksanakan berdasarkan prosedur atau syntax yang diungkapkan oleh [2] dengan penyesuain sebagai berikut:

1. Pada awal pertemuan, peneliti sebagai dosen membagi kelompok mahasiswa, dimana setiap kelompok terdiri dari 2 orang yang akan berperan sebagai problem solver dan listener dengan kemampuan yang heterogen. Mahasiswa diberikan penjelasan mengenai masing-masing tugas problem solver dan listener.

2. Apersepsi diberikan dengan cara menggali pengetahuan mengenai materi yang akan dipelajari. Dimulai dengan menganalisa bukti transaksi yang disediakan.

3. Semua kelompok diberikan pengarahan mengenai materi yang akan dipelajari, kemudian dosen meminta semua kelompok untuk bersama-sama menelaah soal yang diberikan, kemudian menyelesaikan soal tersebut.

4. Mahasiswa yang berperan sebagai problem solver membacakan soal yang diberikan secara lisan, kemudian mahasiswa tersebut merencanakan penyelesaian dari permasalahan yang diberikan tersebut, lalu secara lisan pula mengutarakan proses penalaran yang digunakan untuk menyelesaikan masalah tersebut. 
5. Listener mendorong problem solver untuk berpikir secara lisan dan menggambarkan langkahlangkah penyelesaian masalah tersebut. Listener juga dapat mengajukan pertanyaan-pertanyaan klarifikasi dan menawarkan saran-saran, tetapi harus menahan diri untuk menyelesaikan masalah.

6. Setelah satu permasalahan diselesaikan, mahasiswa berganti peran antara problem solver dan listener.

Hasil dari pembelajaran yang dilakukan di atas terlihat pada pertemuan terakhir yang dilakukan oleh peneliti dengan memberikan posttest. Hasil posttest dari mahasiswa di kelas eksperimen ini memberikan hasil yang cukup memuaskan, dari segi kemampuan pemecahan masalah. Setiap indikator penyusun variabel kemampuan pemecahan masalah mengalami peningkatan yang baik.

\subsubsection{Analisis Data}

Tujuan penelitian ini adalah untuk mengetahui sejauhmana keberhasilan model pembelajaran model pembelajaran Think-Aloud Pair Problem Solving dalam meningkatkan kemampuan pemecahan masalah mahasiswa dalam mata kuliah Praktikum Akuntansi Dasar jika dibandingkan dengan pembelajaran ekspositori. Untuk mengetahui hasil dari penerapan model pembelajaran TAPPS, peneliti melakukan beberapa analisis data pendahulu untuk menentukan alat statistik yang akan digunakan sebagai alat uji.

\subsubsection{Uji Normalitas dan Uji Homogenitas}

Pengujian normalitas dilakukan dengan bantuan software SPSS V.23 dengan menggunakan rumus Kolmogorov- Smirnov untuk pengujian normalitas dan rumus Levene Statistik untuk pengujian homogenitas. Taraf signfikansi yang digunakan dalam uji normalitas ini adalah $\alpha(0,05)$. Dengan syarat jika $p$-value $>\alpha$, maka data dalam sampel yang digunakan berdistribusi normal dan selanjutnya dapat dilakukan uji statistik secara parametrik. Namun apabila $(p$-value $<\alpha)$, maka $\mathrm{H}_{\mathrm{a}}$ diterima, dan pengujian hipotesis dilakukan menggunakan statistik non parametrik. Syarat tersebut juga berlaku untuk pengujian homogenitas.

Pengujian normalitas dan homogenitas yang ini terkait dengan pengujian data yang dimaksudkan untuk mengetahui apakah terdapat perbedaan peningkatan antara skor pretest dan posttest yang diwakili dengan gain yang dicapai antara kelas eksperimen yang menggunakan pembelajaran kolaboratif teknik Think Aloud Pair Problem Solving dan kelas kontrol yang menggunakan pembelajaran ekspositori. Karena ingin melihat perbedaan peningkatan hasil belajar yang diwakili oleh pretest dan posttest, maka dalam pengujian hipotesis ini yang dijadikan sampel datanya adalah peningkatan (gain) kemampuan pemecahan masalah di masing-masing kelas. Tabel berikut akan memperlihatkan hasil pengujian normalitas dan homogenitas dari data gain kemampuan pemecahan masalah pada masing-masing kelas:

Tabel 1. Hasil Uji Normalitas dan Homogenitas

Gain Kemampuan Pemecahan Masalah Kelas Eksperimen-Kontrol

\begin{tabular}{|l|l|l|l|l|}
\hline \multirow{2}{*}{ Sumber Data } & \multicolumn{3}{|l|}{ Normalitas } & Homogenitas \\
\cline { 2 - 4 } & Sig* & Keputusan & Sig** & Keputusan \\
\hline Eksperimen & .200 & Normal & \multirow{2}{*}{.850} & Homogen \\
\hline Kontrol & .200 & Normal & & \\
\hline
\end{tabular}

Pengujian peningkatan (gain) kemampuan pemecahan masalah di masing-masing kelas menunjukkan hasil yang normal dan homogen. Hal tersebut dibuktikan dengan nilai signifikansi masing-masing sampel data lebih dari batas nilai signifikansi yang telah ditentukan yaitu sebesar 0,05. Dari hasil pengujian di atas, maka selanjutnya pengujian yang dilakukan menggunakan statistic parametrik uji independent sample t test 


\subsubsection{Peningkatan Kemampuan Pemecahan Masalah di Kelas Eksperimen}

Berdasarkan pengujian data sebelumnya, didapatkan hasil bahwa data yang dipakai untuk pengujian hipotesis yang pertama berdistribusi normal. Oleh sebab itu statistik parametrik yang digunakan adalah independent sample t-test taraf signifikansi 95\%. Dengan syarat: Jika $p$-value $>\alpha$ maka kemampuan pemecahan masalah mahasiswa dalam mata kuliah praktikum akuntansi dasar di kelas eksperimen setelah melaksanakan proses pembelajaran kolaboratif teknik Think-Aloud Pair Problem Solving sama dengan sebelum melaksanakan proses pembelajaran kolaboratif teknik Think-Aloud Pair Problem Solving.

Berikut peneliti tampilkan hasil pengujian paired sample t-test kemampuan pemecahan masalah di kelas eksperimen

Tabel 2. Paired Sample t-Test Kemampuan Pemecahan Masalah Kelas Eksperimen

\begin{tabular}{|c|c|c|c|c|c|c|c|c|}
\hline & \multicolumn{5}{|c|}{ Paired Differences } & \multirow{3}{*}{$\mathrm{t}$} & \multirow{3}{*}{$\mathrm{df}$} & \multirow{3}{*}{$\begin{array}{c}\text { Sig. } \\
\text { (2-tailed) }\end{array}$} \\
\hline & \multirow{2}{*}{ Mean } & \multirow{2}{*}{$\begin{array}{c}\text { Std. } \\
\text { Deviation }\end{array}$} & \multirow{2}{*}{$\begin{array}{l}\text { Std. Error } \\
\text { Mean }\end{array}$} & \multicolumn{2}{|c|}{$\begin{array}{c}95 \% \text { Confidence Interval } \\
\text { of the Difference }\end{array}$} & & & \\
\hline & & & & Lower & Upper & & & \\
\hline \begin{tabular}{c|l} 
Pai & Pretest \& \\
r 1 1 & $\begin{array}{l}\text { Posttest kelas } \\
\text { eksperimen }\end{array}$
\end{tabular} & $\begin{array}{c}- \\
18.788\end{array}$ & 7.140 & 1.243 & -21.320 & -16.256 & -15.115 & 32 & .000 \\
\hline
\end{tabular}

Terlihat dalam tabel tersebut $p$-value menujukkan nilai yang lebih kecil dari taraf signifikansi yang ditentukan, yaitu sebesar 0,05. Hasil tersebut menunjukkan bahwa di kelas eksperimen terjadi peningkatan kemampuan pemecahan masalah dengan menggunakan model pembelajaran TAPPS. Atau dapat dikatakan bahwa kemampuan pemecahan masalah di masing-masing kelas lebih tinggi dibandingkan dengan sebelum melaksanakan model pembelajaran TAPPS.

Selain pengujian untuk mengetahui mengenai kemampuan pemecahan masalah secara menyeluruh, dalam bagian ini peneliti juga ingin mengetahui bagaimana pembelajaran kolaboratif teknik Think Aloud Pair Problem Solving mempengaruhi kemampuan pemecahan masalah berdasarkan aspek-aspek penyusunnya sebagaimana yang diungkapkan oleh [1]. Pengaruh tersebut dapat digambarkan pada grafik mengenai rata-rata skor pretest sebelum mahasiswa melakukan pembelajaran kolaboratif teknik TAPSS dalam perkuliahan, lalu skor posttest setelah treatment dilakukan, serta perubahan nilai (gain) dari masingmasing indikator kemampuan pemecahan masalah.

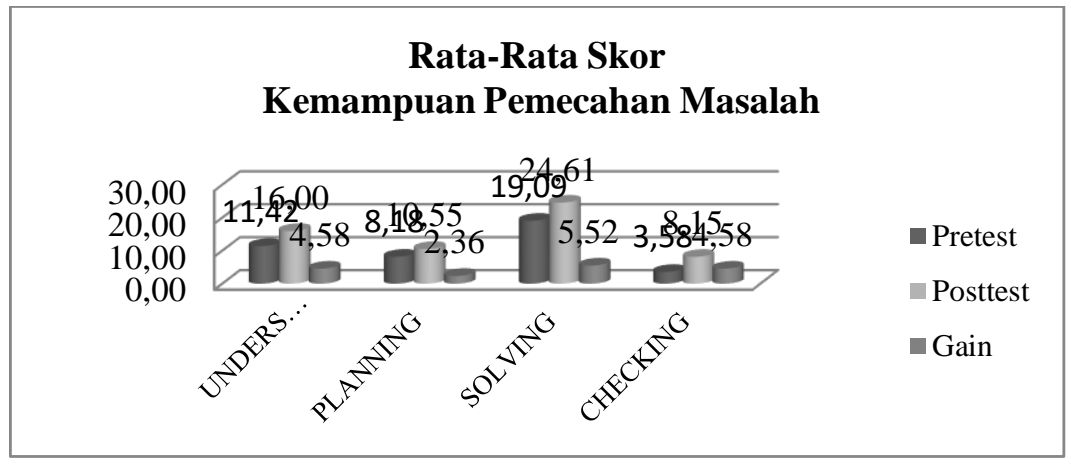

Gambar 1. Grafik Perbandingan Kemampuan Pemecahan Masalah Kelas Eksperimen 
Grafik di atas menunjukan skor rata-rata masing-masing indikator kemampuan pemecahan masalah pada saat pretest, posttest, maupun gain dari kedua tes tersebut. Yang perlu diingat bahwa soal tes yang digunakan dalam pretes maupun posttest penelitian ini menggunakan materi yang berbeda. Tes ini terdiri dari delapan (8) soal, dengan nilai maksimal 10 untuk masing-masing soal, dan nilai yang berbeda untuk setiap indikatornya. Sesuai dengan pedoman penilaian kemampuan pemecahan masalah yang sudah ditentukan. Untuk indikator understanding skor maksimal yang diberikan 2 (dua), planning skor maksimalnya adalah 2 (dua), untuk indikator solving skor maksimalnya 4 (empat) dan terakhir checking memiliki skor maskimal sebesar 2 (dua) poin.

Dalam alat tes penelitian ini, indikator understanding mempunyai skor maksimal 16 untuk 8 (delapan) soal yang disediakan. Skor rata-rata pretest pada indikator ini menunjukan nilai sebesar 11,42 dan mengalami peningkatan sebesar 4,58 dan mencapai nilai rata-rata maksimal sebesar 16 pada hasil posttest. Aspek atau indikator kedua dalam kemampuan pemecahan masalah adalah membuat rencana penyelesaian masalah (planning). Rata-rata peningkatan (gain) sebesar 2,36 poin menunjukkan peningkatan pada saat prestes sebesar 8,183 berubah meningkat menjadi 10,55 pada saat posttest. Aspek selanjutnya dalam kemampuan pemecahan masalah adalah aspek solving. Aspek yang memiliki nilai terbesar ini memperlihatkan hasil yang paling baik. Pada saat pretest, aspek ini menunjukan skor rata-rata sebesar 19,09 mengalami kenaikan sebesar 5,52 poin menjadi 24,61 pada saat posttest. Tahapan atau aspek terakhir dalam kemampuan pemecahan masalah adalah checking. Hal tersebut seringkali menjadi bagian yang diabaikan baik oleh pengajar maupun para mahasiswa, terlihat dalam hasil penelitian ini, aspek pengecekan kembali pada saat pretest hanya menunjukan skor rata-rata sebesar 3,58. Skor rata-rata maksimal pada aspek ini adalah sebesar 16,00 poin, walaupun tidak dapat mencapai skor rata-rata maksimal tetapi setelah melaksanakan pembelajaran kolaboratif dengan teknik Think Aloud Pair Problem Solving (TAPPS) skor rata-rata aspek checking pada kelas eksperimen mengalami perubahan mejadi 8,15 poin. Hal tersebut menunjukkan peningkatan sebesar 4,58 antara hasil pretest dan posttest.

\subsubsection{Perbedaan Peningkatan Kemampuan Pemecahan Masalah di Kelas Eksperimen dan Kelas}

\section{Kontrol}

Tabel 4. Uji Independent Sample t-Test Perbedaan Peningkatan Kemampuan Pemecahan Masalah

Kelas Eksperimen-Kontrol

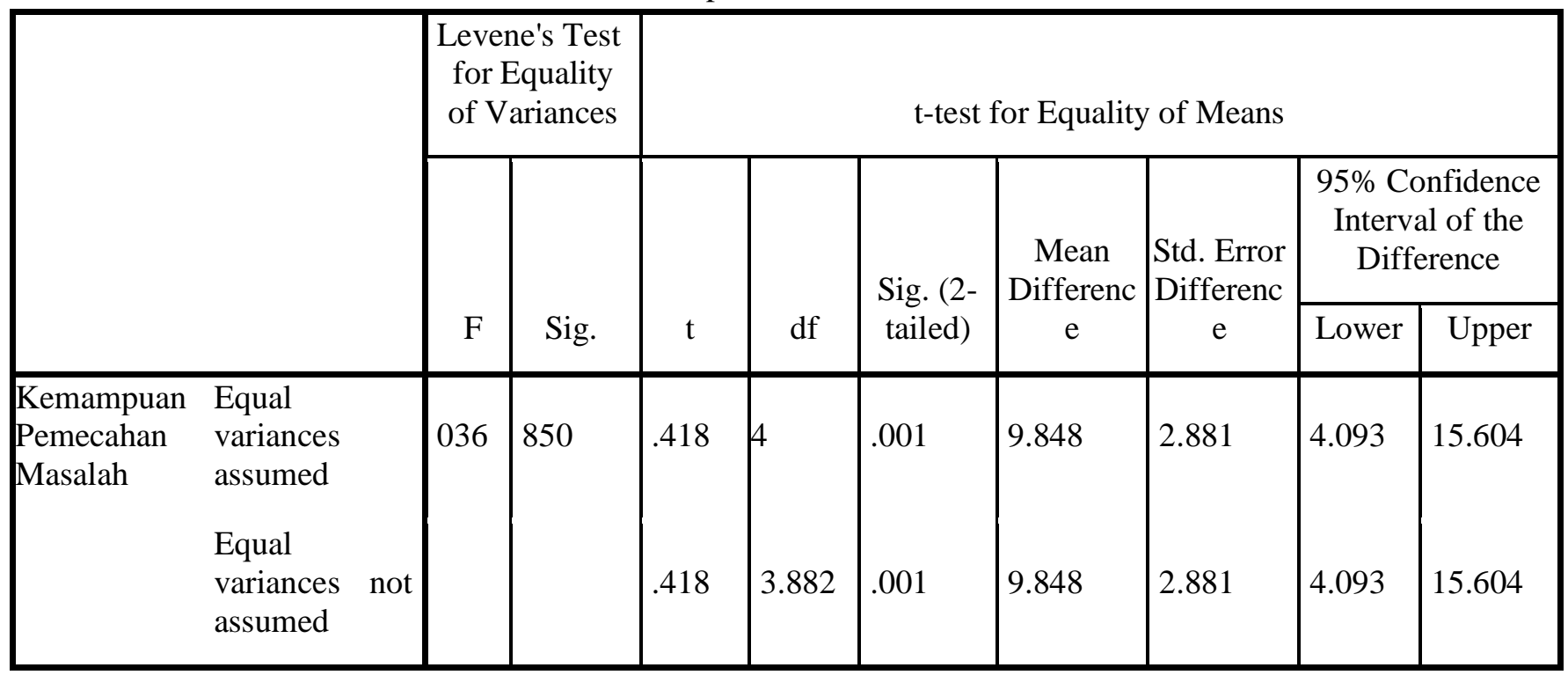


Tujuan utama penelitian ini adalah untuk mengetahui perbedaan peningkatan kemampuan pemecahan masalah dengan menggunakan model pembelajaran Think-Aloud Pair Problem Solving jika dibandingkan dengan pembelajaran yang menggunakan model pembelajaran ekspositori. Dengan bantuan SPSS V.23 berikut ditampilkan hasil pengujian independent $t$-test dan imdependent sample $t$-test dalam tabel dibawah berikut ini:

Tabel 3. Uji Independent $t$-Test Perbedaan Peningkatan Kemampuan Pemecahan Masalah

\section{Kelas Eksperimen-Kontrol}

\begin{tabular}{|c|c|c|c|c|c|}
\hline \multicolumn{3}{|c|}{ Kelas } & $\mathrm{N}$ & Mean & Std. Deviation \\
\hline Kemampuan & Post-Test & Kelas & 33 & 61.03 & 11.952 \\
\hline Pemecahan & Eksperimen & & & & \\
\hline Masalah & $\begin{array}{l}\text { Post Test } \\
\text { Kontrol }\end{array}$ & Kelas & 33 & 51.18 & 11.449 \\
\hline
\end{tabular}

Dari kedua tabel didapatkan interpretasi sebagai berikut:

1. Dari pengujian independent $t$-tes didapatkan hasil mean post test kelas eksperimen lebih tinggi $(61,03)$ jika dibandingkan dengan mean post test kelas control sebesar 51,18. Hal tersebut menunjukkan model pembelajaran Think-Aloud Pair Problem Solving lebih baik untuk meningkatkan kemampuan pemecahan masalah mahasiswa dalam mata kuliah Praktikum Akuntansi Dasar.

2. Pengujian Independent Sample t-Test memperkuat hasil sebelumnya. Dengan menggunakan pengujian ini, terlihat tingkat signifikansi dalam equal variance assumed sebesar $0,001<0,05$. Hal tersebut menunjukkan bahwa ada perbedaan rata-rata kemampuan pemecahan masalah mahasiswa yang menggunakan model pembelajaran TAPPS dengan mahasiswa yang menggunakan model pembelajaran ekspositori.

Selain dari hasil pengujian hipotesis di atas, perbedaan peningkatan kemampuan pemecahan masalah antara kelas eksperimen dan kelas kontrol dapat diindikasikan melalui grafik seperti yang terlihat pada gambar berikut ini.

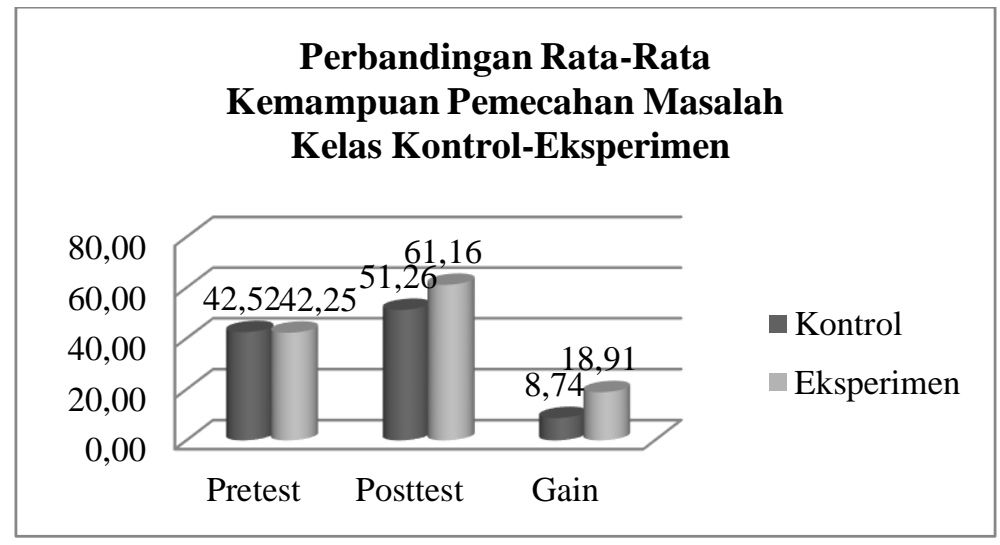

Gambar 2.

Perbandingan Rata-Rata Kemampuan Pemecahan Masalah Kelas Kontrol-Eksperimen

Skor rata-rata pretest kemampuan pemecahan masalah yang dimiliki oleh para mahasiswa di kelas kontrol dan eksperimen menunjukan nilai yang cenderung sama. Kedua kelas ini hanya memiliki perbedaan 
skor rata-rata sebesar 0,27 poin. Dari grafik di atas dapat kita simpulkan bahwa peningkatan lebih tinggi diperoleh kelas eksperimen yang diberikan treatment berupa pembelajaran kolaboratif teknik Think Aloud Pair Problem Solving. Keunggulan gain sebesar 18,91 pada kelas eksperimen menunjukan pembelajaran kolaboratif teknik TAPPS lebih unggul dalam meningkatkan kemampuan pemecahan masalah.

Indikator keberhasilan dari proses pembelajaran adalah N-Gain yang diperoleh masing-masing kelas. Perbandingan hasil $\mathrm{N}$-Gain dari masing-masing kelas dapat kita rinci sebagai berikut.

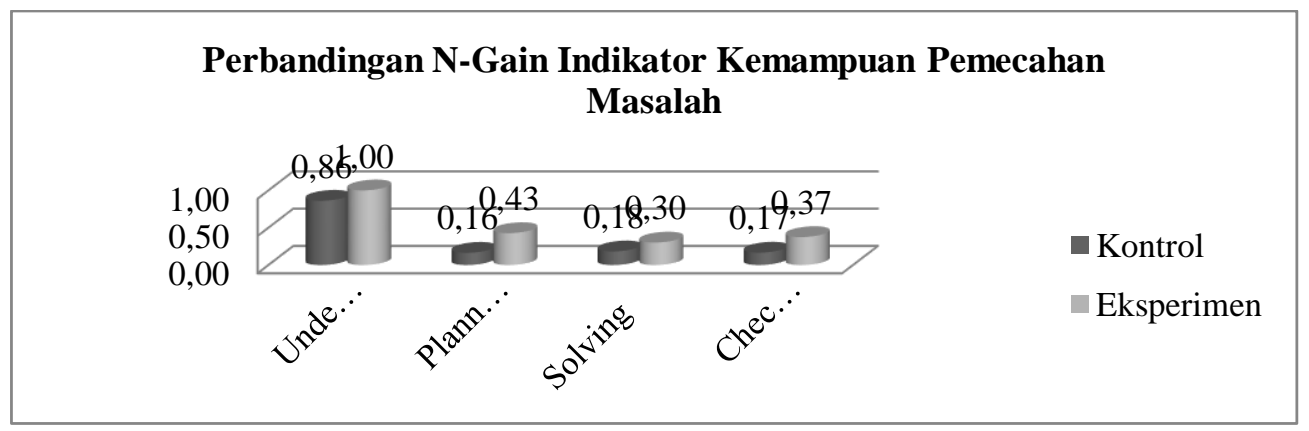

Gambar 3. Perbandingan N-Gain Indikator Kemampuan Pemecahan Masalah

Dari grafik di atas dapat kita simpulkan bahwa aspek-aspek pembentuk kemampuan pemecahan masalah dalam kelas eksperimen mengalami peningkatan yang lebih baik jika dibandingkan dengan kelas kontrol. Peningkatan dari setiap aspeknya, pada kelas sedang termasuk dalam peningkatan sedang yang diwakili oleh nilai $\mathrm{N}$-gain di atas 0,30. Bahkan pada kemampuan untuk memahami masalah (understanding) pada kelas eksperimen mengalami peningkatan yang sempurna, yang diwakili dengan nilai $\mathrm{N}$-Gain sebesar 1,00. Sedangkan hasil yang ditunjukan oleh kelas kontrol mengindikasikan bahwa peningkatan kemampuan pemecahan masalah di kelas tersebut rendah, dengan nilai $\mathrm{N}$-gain berada di bawah 0,30 pada tiga indikator penyusun kemampuan pemecahan masalah. Walaupun pada aspek understanding kelas kontrol memiliki peningkatan yang sedang, tetapi rata-rata $\mathrm{N}$-gain secara keseluruhan menunjukan hasil yang rendah.

\subsection{Pembahasan Hasil Penelitian}

Pada bagian ini peneliti akan membahas perubahan masing-masing indikator pemecahan masalah seperti yang diungkapkan oleh [1]. Aspek yang pertama adalah understanding, menurut [1] ciri bahwa mahasiswa paham (understand) terhadap isi soal adalah mahasiswa dapat mengungkapkan pertanyaanpertanyaan yang terkandung dalam sebuah soal. Dalam tahapan understanding ini mahasiswa harus dapat memahami kondisi soal atau masalah yang ada pada soal tersebut. Ciri bahwa mahasiswa paham terhadap isi soal ialah mahasiswa dapat mengungkapkan pertanyaan-pertanyaan beserta jawabannya. Dari pengujian perbandingan antara kelas eksperimen dan kelas kontrol yang diwakili dengan N-Gain yang diperoleh masing-masing kelas tersebut aspek understanding memperlihatkan nilai yang tinggi. Dalam pembelajaran akuntansi, aspek memahami apa yang menjadi permasalahan ini menjadi sangat penting untuk dikuasai. Sebagaimana yang diutarakan oleh Libby \& Luft dalam [5] yang menyatakan bahwa salah satu yang harus dimiliki seseorang kaitannya dengan kemampuan bidang akuntansi adalah kemampuan untuk menganalisis data-data yang diperlukan untuk menyelesaikan permasalahan akuntansi. Ketika mahasiswa dilatih untuk dapat menganalisis data-data yang dibutuhkan dalam menyelesaikan permasalahan, bahkan mengetahui permasalahan apa yang terkandung dalam data-data yang diketahui, maka aspek understanding dalam kemampuan pemecahan akan meningkat.

Aspek kedua dari kemampuan pemecahan masalah adalah planning. Menurut [1], pada tahap ini mahasiswa harus memikirkan langkah-langkah apa saja yang penting dan saling menunjang untuk dapat memecahkan masalah yang dihadapinya dengan pengetahuan yang memadai mengenai permasalahan 
tersebut. Sebelum melakukan penyelesaian masalah, mahasiswa diharapkan dapat menyusun rencana. Semakin terlatih mahasiswa untuk membuat rencana penyelesaian masalah, maka rencana yang disusunnya akan semakin rinci dan berkembang sesuai dengan interpretasinya, tanpa menghilangkan cara menyelesaikan masalah yang sudah baku ditetapkan. Hal tersebut menjadi nilai tambah dalam proses pembelajaran kolaboratif teknik TAPPS dibandingkan pembelajaran ekspositori. Pada proses pembelajaran ekspositori yang dilakukan dengan metode ceramah dan tanya jawab, mahasiswa tidak dituntut untuk menyusun sebuah rencana untuk menyelesaikan permasalahan.

Ketika rencana telah dibuat dan dirasa sudah sesuai dengan hal-hal yang mendasari permasalahan tersebut, langkah selanjutnya dalam tahapan pemecahan masalah yang dikemukakan oleh [1] adalah menyelesaikan masalah (solving). Pada tahapan ini juga sebetulnya menegaskan bahwa lingkungan belajar kolaboratif dikembangkan berdasarkan asumsi bahwa pengetahuan dibentuk melalui konteks sosial. Problem solver berkewajiban untuk memberikan penjelasan kembali kepada listener bagaimana proses solving itu dapat dicapai melalui planning yang dibuat sebelumnya. Kenyataan tersebut membuktikan kebenaran atas apa yang diungkapkan oleh Jhon Dewey (1916) dalam [5] bahwa "pendidikan adalah proses sosial melalui kelompok, dimana para pebelajar memperoleh dan berbagi pengalaman baru yang bermakna”. Pelaksanaan rencana sebagai proses penyelesaian masalah (solving) memberikan pengalaman baru yang bermakna bagi masing-masing mahasiswa dalam kelompoknya. Bagi problem solver, latihan untuk menyusun rencana, melaksanakan rencana, lalu menjelaskan penyelesaian masalah kepada listener memacu kemampuan penyelesaiannya semakin tinggi. Tanggung jawab sosial yang diemban oleh problem solver ketika menjelaskan kepada listener sampai pada keinginan agar apa yang dijelaskannya betul-betul dapat dipahami dan membentuk sebuah pengetahuan baru yang dimiliki oleh listener. Sedangkan bagi listener, pemahaman baru akan muncul ketika problem solver menjelaskan bagaimana sebuah rencana disusun dan dilaksanakan untuk menyelesaikan sebuah permasalahan. Hubungan tersebut pada akhirnya menciptakan rasa saling ketergantungan dan tanggung jawab sesama anggota kelompok yang ditopang oleh kemandirian dari setiap individu yang teribat dalam interaksi sosial melalui pembelajaran kolaboratif teknik Think Aloud Pair Problem Solving ini.

Aspek dan tahapan akhir dalam kemampuan pemecahan masalah yang dikemukakan oleh [1] adalah checking atau peninjauan kembali. Proses akhir dalam penyelesaian masalah ini bukan hanya memeriksa kembali apakah rencana yang dibuat sebelumnya sudah sesuai dengan permasalahan yang diberikan, atau apakah pelaksanaan rencana tersebut sudah benar. Tahapan akhir ini juga merupakan tahapan yang dilakukan untuk membuat kesimpulan dan penafsiran mengenai solusi yang diperoleh melalui tahapan-tahapan sebelumnya. Nilai gain ternormalisasi yang ditunjukan oleh kelas kontrol mengindikasikan bahwa mahasiswa tidak diberikan kesempatan untuk menginterpretasikan pengetahuan yang didapatnya melalui pemecahan masalah yang dilakukannya. Mahasiswa hanya menyelesaikan masalah berdasarkan cara yang telah diberikan oleh pengajar tanpa melakukan pengkajian lebih dalam untuk mencapatkan cara lain untuk menyelesaikan permasalahan yang diberikan. Dengan menggunakan pembelajaran kolaboratif teknik Think Aloud Pair Problem Solving, tahapan checking ini menjadi aspek yang penting dalam proses pembelajaran. Tahapan ini menjadi ajang diskusi bagi anggota kelompok yang terdiri dari problem solver dan listener untuk berdiskusi menyelesaikan permasalahan yang diberikan. Ketika problem solver menjelaskan penyelesaian permasalahan kepada listener secara keseluruhan lalu listener mencoba memahami apa yang dijelaskan padanya, pada saat itulah listener memiliki kesempatan untuk mencerna, dan menginterpretasikan apa yang dipahaminya.

Teknik Think Aloud Pair Problem Solving menjadi bagian dari teknik pembelajaran kolaboratif yang spesifik bertujuan untuk meningkatan kemampuan pemecahan masalah mahasiswa. Tahapan dalam teknik pembelajaran ini menuntut pengajar untuk menyediakan permasalahan-permasalahan yang dapat memacu peningkatan aspek-aspek dalam kemampuan pemecahan masalah. [2] mengemukakan bahwa masalah-masalah yang disusun oleh pengajar harus melibatkan mahasiswa dalam keterampilan 
penyelesaian masalah dasar seperti mengidentifikasi sifat dasar masalah, menganalisis pengetahuan dan keterampilan yang dibutuhkan untuk mencapai sebuah solusi, mengidentifikasi solusi potensial, memilih solusi terbaik, dan mengevaluasi hasil-hasil potensial.

Pembelajaran kolaboratif teknik Think Aloud Pair Problem Solving dalam penelitian ini dilaksanakan dengan tahapan yang sama dengan tahapan yang dilakukan oleh penelitian lainnya yang menggunakan teknik pembelajaran ini dalam bidang lain. Seperti penelitian yang dilakukan oleh [6] yang melaksanakan pembelajaran ini pada bidang matematika, atau [7] yang menggunakan pembelajaran ini pada bidang pertanian. Apapun bidang yang menjadi subjek pelaksanaan pembelajaran ini tahapan serta tujuan akhir yang ingin dicapai sama. Para peserta didik dibagi peran menjadi problem solver dan listener dengan tujuan akhir akhir adalah masing-masing peran dapat menyelesaikan permasalahan dengan cara yang telah ditentukan, bahkan dapat menemukan cara baru secara bersama untuk menyelesaikan permasalahan masalah yang diberikan. Diskusi dalam penyelesaian permasalahan tersebut dilakukan pada bagian akhir pembelajaran ini, karena listener tidak boleh memberikan jawaban yang benar apabila mengetahui penyelesaian yang benar terlebih dahulu, karena pada pembelajaran ini melatih agar peserta didik dapat mengkonstruksi pengetahuan yang dimilikinya dengan pemahaman individual yang dimilikinya.

\section{KESIMPULAN DAN SARAN}

\subsection{Kesimpulan}

1. Kemampuan pemecahan masalah mahasiswa dalam mata kuliah Pengantar Akuntansi setelah melaksanakan proses pembelajaran kolaboratif teknik Think-Aloud Pair Problem Solving lebih tinggi dibandingkan dengan sebelum melaksanakan proses pembelajaran kolaboratif teknik Think-Aloud Pair Problem Solving.

2. Peningkatan kemampuan pemecahan masalah mahasiswa dalam mata kuliah Pengantar Akuntansi yang melaksanakan proses pembelajaran kolaboratif teknik Think-Aloud Pair Problem Solving lebih tinggi dibandingkan dengan mahasiswa yang melaksanakan proses pembelajaran ekspositori.

\subsection{Saran}

Bagi peneliti selanjutnya, perlu dilakukan pelaksanaan penelitian yang lebih lama, agar dampak yang ditimbulkan oleh pelaksanaan pembelajaran TAPPS terkait dengan kemampuan pemecahan masalah lebih representatif. Selain itu objek penelitian juga bias lebih dikembangkan, tidak hanya dilaksanakan di satu institusi Pendidikan tinggi saja.

\section{REFERENSI}

[1] G. Polya, "Polya_HowToSolveIt.pdf." 1985.

[2] dan C. H. M. Barkley, Elizabert E., K. Patricia Cross, Collaborative Learning Techniques. Bandung: Nusa Media, 2012.

[3] R. S. Yohanes, "Teori Vygotsky dan implikasinya terhadap pembelajaran matematika," J. Widya War., vol. XXXIV, no. 2, pp. 854-1981, 2010.

[4] Sugiyono, Metode Penelitian Pendidikan. Bandung: Alfabeta, 2012.

[5] L. Agustina, "Upaya Meningkatkan Aktivitas Dan Hasil Belajar Mahasiswa Melalui Pembelajaran Kolaboratif Dengan Pendekatan Pemecahan Masalah,” Din. Pendidik. Unnes, vol. 2, no. 3, pp. 271- 
314, 2007.

[6] N. S. H. Simpol, M. Shahrill, H. C. Li, and R. C. I. Prahmana, "Implementing thinking aloud pair and Pólya problem solving strategies in fractions," J. Phys. Conf. Ser., vol. 943, no. 1, 2018.

[7] M. Pate and G. Miller, "Effects of Think-Aloud Pair Problem Solving on Secondary-Level Students' Performance in Career and Technical Education Courses," J. Agric. Educ., vol. 52, no. 1, pp. 120-131, 2011. 